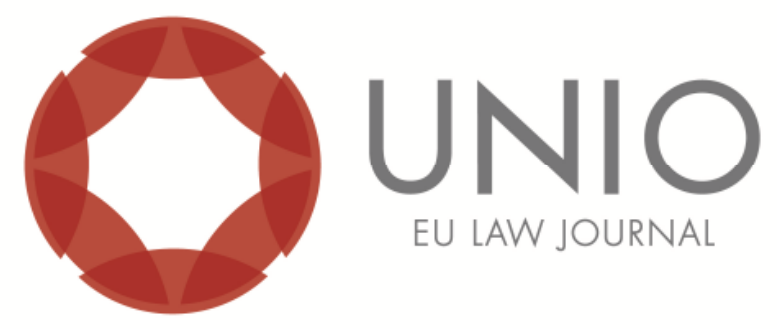

\title{
The Right of Free Movement and the Access To Social Protection in the EU: The Economical Dimension. Notes on the Case Elisabeta Dano v Jobcenter Leipzig, C-333/13
}

\author{
Daniela Guimarães*
}

ABSTRACT: This article seeks to analyse the impact of the Court of Justice of the European Union's (CJEU) decision in the Dano judgement concerning the free movement of EU citizens and their cross-border access to social benefits. The debate about social tourism or welfare migration has been acrimonious in the last years. The Member States face new challenges concerning the possibility of excluding economically inactive European Union (EU) citizens from other Member States from special non-contributory social benefits. However, if on one hand we have the need to protect the financial sustainability of the Member States, as non-active EU citizens from other Member States can represent a burden on their social assistance systems, on the other hand, we also need to respect one of the EU's most basilar principles: the probibition of discrimination on grounds of nationality. The CJEU has decided that the economically nonactive citizens of other Member States can only claim equal treatment in regard to access to social benefits, when they have a right of residence under Directive 2004/38 in the host Member State.

KEYWORDS: citizenship of the European Union - fee movement of persons - equal treatment - economically inactive nationals - exclusion from the access to social benefits.

\footnotetext{
* Collaborating Member of the Centre of Studies in European Union Law of University of Minho.
} 


\section{Introduction}

The conditions under which the EU citizens residing in the territory of another Member State can claim non-contributory social benefits have enjoyed particular attention from the Member States since the recognition of the right to free movement to all the EU Citizens ${ }^{1}$. In recent years, much as a result of the economic crisis in the EU, the debate has risen in tandem with the Member States submitting arguments in the sense of not granting non-contributory social benefits to those who solely seek jobs under the justification of the social tourism phenomenon ${ }^{2}$. The legal discussion has been focused on the rights of economically inactive migrating Union citizens to social benefits in the host Member States. It started with the statement by the Court of Justice that, since the introduction of European citizenship by the Maastricht Treaty, noneconomic migration between Member States also triggers the application of the Treaty prohibition of discrimination on grounds of nationality in the host State (now art. $18^{\text {th }}$ of the $\mathrm{TFEU}^{3}$ ). In its jurisprudence prior to the coming into force of Directive 2004/38/EC ${ }^{4}$, the CJEU confirmed that this principle also applies to social assistance benefits, as well as to other non-contributory benefits ${ }^{5}$, such as student maintenance grants ${ }^{6}$.

The European Commission, as defender and promoter of the right of free movement of EU citizens ${ }^{7}$, has sought to allay the concerns of Member States through studies ${ }^{8}$ and communications that prove that economically inactive EU citizens who reside in Member States other than the ones of their nationality represent a reduced percentage of public expenditure.

In this context, we seek to analyse the decision of the CJEU issued in November of 2014 concerning the Dano judgement ${ }^{9}$. According to this decision, a EU citizen residing in a Member State other than the one of its

\footnotetext{
${ }^{1}$ The recognition of the free movement rights to all the EU citizens was only possible thanks to the establishment of the European Union citizenship (with the Treaty of Maastricht) as the fundamental status of all the nationals of the Member States. With such recognition, the circulation of non-active citizens in the EU territory became possible, raising doubts concerning the social protection attributed by the hosting Member States to such individuals. Judgments such as Grzelcaylk, Martinez. Sala, Collins, Trojani, Bidar, Vatsouras and Ruiz Zambrano constitute the most interesting line of ECJ decision on in this matter.

${ }^{2}$ In practical terms, the fear is that non-nationals exercising their right of free movement in the EU territory would represent added cost for Member States by enjoying, without any contribution, the social benefits that they provide.

${ }^{3}$ See ECJ decision on Martinez Sala, 12th May 1998, process C-85/96, text available at: http://eurlex.europa.eu/legal-content/EN/TXT/?qid=1431261716626\&uri=CELEX:61996CJ0085.

4 Directive 2004/38/CE dated April 29th 2004, by the European Parliament and Council of Europe on the right of citizens of the Union and their family members to move and reside freely within the territory of the Member States, text available at http://eur-lex.europa.eu/legalcontent/EN/TXT/PDF/?uri=CELEX:32004L0038\&qid=1425914435266\&from=EN.

5 See ECJ decision on Grzelczyle, dated September 20th 2001, case C 184/99, number 44, text available at http://eur-lex.europa.eu/legal-content/EN/TXT/?qid=1425986794699\&uri=CELEX: 61999CJ 0184.

${ }^{6}$ See ECJ decision on Bidar, 15th March 1998, process C-209/03, text available at: http://eur-lex. europa.eu/legal-content/EN/TXT/?qid=1431262526034\&uri=CELEX:62003CJ0209.

7 As stated in articles 21 st and 45 th of the TFEU.

8 See ICF GHK, Milieu Ltd, "A fact finding analysis on the impact on the Member States' social security systems of the entitlements of non-active intra-EU migrants to special non-contributory cash benefits and healthcare granted on the basis of residence", dated October $14^{\text {th }} 2013$, text available at ec.europa.eu/social/BlobServlet?docId=10972\&langId=en.

${ }^{9}$ See ECJ decision on Dano, 11 th november 2014, process C - 333/13, text available at http://eurlex.europa.eu/legal-content/EN/TXT/HTML/?uri=CELEX:62013CJ0333\&from=EN.
} 
nationality cannot claim the grant of non-contributory social benefits, granted to nationals who are in the same situation, when they do not fulfil the requirements of the Directive $2004 / 38 / \mathrm{EC}^{10}$ on the free movement of EU citizens concerning the right of residence.

If on one hand, the CJEU's decision puts an end to the disturbances related to to the fact that freedom of movement of EU citizens can lead to the so-called phenomenon of social tourism, on the other, it seems to be a setback in regard to to the densification of the exercise of free movement and the prohibition of discrimination on grounds of nationality ${ }^{11}$, milestones of the European citizenship citizenship as the fundamental status of all the EU citizens ${ }^{12}$.

\section{Case Description}

Two Romanian nationals, Ms Elizabeta Dano and her son Florin, have brought proceedings before the Social Court of Leipzig (Germany), against Jobcenter Leipzig, which refused to grant them benefits by way of basic provision $^{13}$.

It has been understood that Ms Dano did not enter Germany in order to seek work there and, although she has requested benefits by way of basic provision, which were only available for jobseekers, it was apparent from the facts that she was not seeking employment.

She had not been trained in any profession and, to date, she had not worked in Germany or Romania. Notwithstanding, she and her son had apparently been residing in Germany since November of 2010 , living in the home of Ms Dano's sister, who provided for them. Ms Dano received, with regard to her son, child benefits amounting to $€ 184$ per month and also child support provisions amounting to $€ 133$ per month ${ }^{14}$.

Taking into account the fact that German law in its Social Code ${ }^{15}$ dictates that only a limited number of beneficiaries are entitled to basic provision, excluding foreign nationals (and their families) whose right of residence is only justified by the search for employment, the Leipzig's Jobcenter refused to grant the basic provision to Ms. Dano. The applicant contested this decision arguing that such a norm was in contradiction to EU law in regard to the free movement of EU

\footnotetext{
${ }_{10}$ Directive 2004/38/CE dated April 29th 2004, by the European Parliament and Council of Europe on the right of citizens of the Union and their family members to move and reside freely within the territory of the Member States, text available at http://eur-lex.europa.eu/legalcontent/EN/TXT/PDF/?uri=CELEX:32004L0038\&qid=1425914435266\&from=EN.

${ }^{11}$ See article 21 st paragraph 2 of the EU Charter.

${ }^{12}$ In this context it is important to make a reference to the background of the current article $21^{\text {st }}$ of the TFEU that grants the right of free movement and residence in EU territory to all nationals of a Member State. This possibility began with the Mastricht Treaty that established the EU citizenship. Previously, this right was associated solely to the condition of worker (or service provider) as an economic category. The Rome Treaty's logic, on this topic, was purely economical in nature, since its main concern was the establishment of the single market. The logic today, however, is of a Union of citizens in which the European citizenship is a fundamental status of every national of all Member States. Furthermore, in the present day, the right of free movement and residence extends its protection to certain family members of the EU citizens, regardless of their respective nationalities; the said treatment is justified as a way of facilitating nationals their exercise of this particular right.

${ }^{13}$ Benefits to cover subsistence costs for jobseekers that allow them to lead a life in keeping with human dignity. In this context, it is used the CJEU's terminology "benefits by way of basic provision".

${ }^{14}$ Benefits that were not further discussed in the case.

15 Article 7 of Book II of Sozialgesetzuch Erstes Buch, following "SGB II".
} 
citizens and the prohibition of discrimination on grounds of nationality. The Social Court of Leipzig decided to continue the proceedings and to refer a series of questions to the CJEU concerning:

a)- the scope ratione personae of the Article 4 of the Regulation No 833/2004 in order to assess if the prohibition of non-discrimination on grounds of nationality, in this context, also applied to special non-contributory benefits ${ }^{16}$;

b)- the compliance with the EU law of the exclusion by the Member States of EU citizens in need of access to social benefits, in order to protect their welfare systems ${ }^{17}$;

c)- the compatibility with the Charter of Fundamental Rights of the European Union (EU Charter), specifically with its Articles 1, 20 and 51, of the limitation of the non-contributory benefits to the necessary funds for return to the home State.

In response to the questions raised by the Social Court of Leipzig, the CJEU has held in that for the purpose of having access to certain social benefits (such as German benefits by way of basic provision), nationals of other Member States can claim equal treatment with nationals of the host Member State only if their residence complies with the conditions of Directive 2004/38 on free movement of EU citizens.

On this matter, the CJEU recalls that, according to Directive 2004/38, the host Member State is not obligated to concede social benefits to nationals from other Member States during the first three months of residence ${ }^{18}$.

When the period of residence is longer than three months but less than five years (the period that is at issue in the case), one of the conditions which the directive lays down for the right of residence is that economically inactive persons must have sufficient resources for their own subsistence ${ }^{19}$.

The directive intends to prevent economically non-active EU citizens from using the host Member State's welfare system to fund their own means of living $^{2021}$. Consequently, the Member States must have the possibility of refusing to grant social benefits in a situation where an economically inactive EU citizen exercises his right to freedom of movement in order to obtain another Member State's social assistance and does not gather the sufficient resources to claim the right of residence. However, such a decision must be taken in a process where each individual case is examined without taking into account the social benefits claimed.

Admitting that people who do not benefit from the right of residence, within

\footnotetext{
${ }^{16}$ Encased in article 3rd paragraph 3 and article 70 of the Regulation.

${ }^{17}$ Specifically with articles 18 and 20 paragraph 2 of the TFEU and articles 24 paragraph 2 of the EU directive 2004/8 and 70 of the Regulation $n^{\circ} 883 / 2004$.

18 See article 6 of the Directive 2004/38.

${ }^{19}$ See article 7 of the Directive 2004/38.

20 According to article 8 paragraph 4 of the EU directive $n^{\circ} 2004 / 8$, citizens have sufficient resources when their income is above the level of resources below which the nationals can enjoy social benefits or above the minimum pension given by social security provided by the host Member States.

${ }^{21}$ It is important to note that the deadlines predicted have their origin in Antonissen's decision dated February 26th 1991, Case C-292/89, in which the CJEU ruled that the principle of free movement must be interpreted in ample terms so that it includes the workers prerogative to resided in another Member State, during a reasonable period, while searching for employment. According to the CJ, the duration of the said deadline should be determined considering the need to allow the worker to access, in the Member State, the employment opportunities correspondent to their professional qualifications and take the necessary measures to ensure hiring; moreover, given the absence of EU dispositions that fixate the period of residence of these workers, it was up to the Member States to determine a reasonable period for that end.
} 
the conditions set out in Directive 2004/38, can claim a right to social benefits in the same conditions applied to national citizens goes against the Directive's goals in "preventing Union citizens who are nationals of other Member States from becoming an unreasonable burden on the social assistance system of the host Member State" 22

In these circumstances, the Court declared that Directive 2004/38 and Regulation No 833/2004 on the coordination of social security systems do not preclude legislation of a Member State under which nationals of other Member States are excluded from entitlement to certain special non-contributory cash benefits, although they are "granted to nationals of the host Member State who are in the same situation, in so far as those nationals of other Member States do not have a right of residence under the directive in the host Member State."23

At last, the court pointed out that the Regulation No 833/2004 does not intend to lay down the conditions creating the right to the special non-contributory benefits. Therefore the Member States have the competence to determine the conditions for granting such benefits and also to define the extent of its social cover. In this matter, the Member States are not implementing EU law and consequently, the Charter of Fundamental Rights of the EU is not applicable.

In conclusion, according to the CJEU, as far as social benefits are concerned, Ms Dano and her son are not entitled to claim equal treatment with nationals of the host Member State once it is established that their right of residence in Germany does not comply with the conditions of the Directive 2004/38.

\section{Comments on the CJEU's Decision}

In a decontextualized manner, the Dano's judgement appears to be assertive and substantiated. However, looking at previous decisions of the CJEU, it seems that this one goes in a different direction. In fact, it raises doubts concerning the real reach of the European citizenship as its very core hinges on free movement and the prohibition of discrimination on grounds of nationality.

\subsection{The Right of Free Movement and the Access to Special Non- Contributory Cash Benefits}

Although initially the Treaties defined free movement in connection with the exercise of an economic activity, today its application has widened, being practically unconditional for the economically active citizens ${ }^{24}$ and also extending to non-active citizens who seek jobs in another Member State. The right to free movement is now part of the core of EU citizenship, which means that any national from a Member State can exercise it freely.

However, if in the first case, the right to residency of a national from a different Member State is subject to deadlines that shall be established reasonably by the host Member State; on the second one, all economically inactive nationals shall prove viable economic self-sufficiency well as possess valid health insurance ${ }^{25}$.

The CJEU has, in the last years, been responsible for decisions that resulted in

\footnotetext{
22 See ECJ decision on Dano, number 74.

${ }^{23}$ See ECJ decision on Dano, number 84.

24 See J Cunha Rodrigues, "Liberdade de Circulação e Permanência", in Carta dos Direitos Fundamentais da União Europeia Comentada, ed. Alessandra Silveira and Mariana Canotilho, (Coimbra: Almedina, 2013) 522-523.

25 See Directive 2004/38.
} 
the widening of its exercise, withdrawing even further from its traditional economic dimension ${ }^{26}$ and seeking the full protection of those who are non-active, to ensure that they do not suffer from reverse discrimination ${ }^{27}$ or lack of protection from the Host Member States ${ }^{28}$.

The ruling in the Dano case seems to invert this tendency and the traditional approach to the right of free movement seems to gain new life, proving that the economic dimension of this right might have faded but was never truly gone.

As expected, several Member States applauded the ruling of the $\mathrm{CJEU}^{29}$ as it boldly addressed the weight of economically inactive EU citizens in their welfare systems.

It is clear that the Court favoured the financial sustainability of Member State's welfare systems. However, is this decision really justified by the current situation of the Member States?

Complaints about occurrences of fraud and systematic abuse of social security systems in connection with the freedom of movement are not recent. In May of 2013, the United Kingdom, Austria, Germany and the Netherlands came forward with these issues to the European Commission that argued, in response, that EU law provided sufficient safeguards against abuse ${ }^{30}$.

In spite of this, the European Commission took the initiative by proposing measures that would "make a difference" 31 , having created a practical guide that clarified the criterion of "habitual residency" frequently used in regulations concerning the matters of free movement and access to the Member State's welfare systems ${ }^{32}$.

These measures were based on a report mandated by the European Commission and made public in October of 2013, which focused on analysing the impact on the Member States' social security systems of the entitlements of nonactive intra-EU migrants to special non-contributory cash benefits and healthcare granted on the basis of residence ${ }^{33}$.

The report concluded that non-active EU migrants represented a very small share of the total population in each Member State accounting for between $0.7 \%$ and $1.0 \%$ of the overall EU population. Furthermore, on average EU migrants are

\footnotetext{
${ }_{26}$ See, in this matter, the jurisprudence of the CJEU, especially, on the following rulings: ECJ decision on Metock, case C-127/08, dated July 25 th 2008; case Ruiz Zambrano, case C-34/09, dated March $8^{\text {th }} 2011$.

27 Approached in the already referred ECJ decision on Zambrano, the opposite discrimination occurs when the limitation of the freedom of EU citizens to invoke their fundamental rights protected by EU jurisdiction rests on the exercise of the freedom of movement.

${ }^{28}$ See ECJ decision on Michel Trojani, case C-465/02, dated September 7th 2004, text available at http:/ / curia.europa.eu/juris/ showPdf.jsf?text $=\&$ docid $=49457 \&$ pageIndex $=0 \&$ doclang $=$ fr\&mode $=$ st \&dir $=\&$ occ $=$ first\&part $=1 \& \operatorname{cid}=258119$

${ }_{29}$ To note that the United Kingdom was the Member State that publicly manifested greatest contentment with it.

${ }^{30}$ See Speech by the then EU Justice Comissioner Viviane Reding at the Justice and Home Affairs Council on December $5^{\text {th }} 2013$, text available at http://europa.eu/rapid/press-release SPEECH13-1025 en.htm.

31 See Communication from the Commission to the European Parliament, the Council, the European Economic and Social Committee and the Committee of the Regions dated November $25^{\text {th }} 2011$ "Free movement of EU citizens and their families: Five actions to make a difference", text available at http://ec.europa.eu/justice/citizen/document/files/com 2013837 free-move ment en.pdf

${ }^{32}$ See http://europa.eu/rapid/press-release IP-14-13 en.htm;\%20file:///Users/utilizador/Down loads/EN $\% 20-\% 20$ Practical $\% 20$ Guide $\% 20$ December $\% 202013 \% 20(17-02-2014)$.pdf

${ }^{33}$ See ICF GHK, Milieu Ltd, op. cit.
} 
more likely to be employed than nationals living in the same country ${ }^{34}$.

On the other hand, the report found little evidence to suggest that the main motivation of EU citizens to migrate and reside in a different Member State is benefit-related as opposed to work or family-related. In truth, citizens from other Member States do not represent a bigger share on the access to social benefits. Specifically concerning the special non-contributory cash benefits, the study shows that EU migrants account for a very small share of beneficiaries representing less than $1 \%$ of all the beneficiaries in countries such as Austria or Portugal and between 1 and 5\% in countries like Germany, the Member State where the facts of the Dano case took place ${ }^{35}$.

The conclusions of the report were clear, stating that the share of non-active intra EU migrants was very small and that they accounted for a similarly limited share of special non-contributory cash benefit recipients, making the budgetary impact of such claims on national welfare provisions very low.

Following this brief contextual analysis, it is evident that the CJEU's competence on social policy and access to social benefits is limited by the EU Treaties $^{36}$. However, that reason alone does not justify the cautious view of the court, especially if we analyse some of its previous decisions on these matters.

\subsection{Equal Treatment and Right of Residency: Other CJEU's Decisions}

One of the key elements of the Dano case was the determination of the scope of equal treatment applied to the entitlement to special non-contributory cash benefits based on the right of residency. The Court determined that equal treatment shall only be applicable, in light of Directive 2004/38, if the national from a different Member State has the right of residency in the host Member State.

In other words, the Court determined that the national from another Member State that does not have a right of residency in accordance with the Directive, cannot use the prohibition of discrimination on ground of nationality as a reason to have access to social benefits.

The provision on equal treatment seems to be applied only when the EU citizen has a permanent right of residency in accordance with Directive 2004/38.

In a similar case involving a French citizen resident in Belgium. Michel Trojani, the CJEU admitted that an EU citizen could enjoy a right of residence just by the direct application of the article 20 of the TFEU even in a situation where the necessary requirements of the Directive were not fulfilled ${ }^{37}$. Furthermore, just like Ms. Dano, Michel Trojani also did not have sufficient resources for himself while holding a permit for temporary residency. In this case, the French citizen asked the Belgian government for the concession of special non-contributory cash benefits but the request was refused.

As Trojani was assigned to a salaried activity in favor of the Salvation Army,

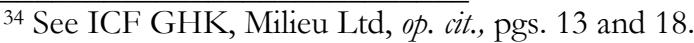

${ }^{35}$ See ICF GHK, Milieu Ltd, op. cit., pgs. 67-77

${ }^{36}$ In this regard, article 4 of the TFEU determines that the Union shares competence with Member States in the matter of social policy in the terms explicitly laid down by the Treaties. To this one we add article 34 of the EU Charter that states that all individuals that reside and move within the European Union have a right to the social security benefits in light of European Union Law and national legislation and practices. On another hand, the EU recognizes and respects the right to social and housing assistance in order to ensure a dignified existence to those who do not have enough means to have one. However, once more this is achieved according to EU Law and national legislation and practices.

${ }^{37}$ See ECJ decision on Michel Trojani, op. cit., number 46.
} 
the CJEU held that Trojani should be classified as employed. However, the CJEU went further and accessed, if he was to be considered unemployed for this purpose, the CJEU whether or not a temporary residency card would be sufficient for the granting a non-contributory cash benefit. In this case, the Court considered that the existence of a permit for temporary residency allowed him to petition for non-contributory cash benefits on grounds of the general principle of nondiscrimination on grounds of nationality ${ }^{38}$.

In the Dano case, the Court did not reach a similar consensus despite the fact that both Ms. Dano and her son legally resided in Germany and both held a temporary residency permit. Although the regulations applied to the situations were different ${ }^{39}$, Directive $90 / 364^{40}$ also intended to avoid situations in which intra EU migrants become a burden on the social assistance system of the host Member State.

Following the observations of the Advocate General Melchior Whelet ${ }^{41}$, the Court, in the Dano decision, stated that any unequal treatment among EU citizens who have made use of their freedom of movement and residence and nationals of the host Member State with regard to the grant of social benefits is an inevitable consequence of Directive 2004/38 that contains a clear concern to avoid creating a burden on the social assistance systems of the Member States.

There is an unequivocal change in direction of the CJEU's ruling representing, in our view, a retreat on the definition of the scope of action of Article 18 of the TFEU. Until now, temporary residency, as decided on the Trojani case, would be sufficient to demand equal treatment - and thus accessing to non-contributory cash benefits - but after this ruling it seems that equal treatment can only to be attained in case of permanent residency. As the CJEU decided in the Dano case, it is admissible for a Member State to deny non-contributory cash benefit entitlements to nationals of other Member States if these do not meet the criteria of the Directive 2004/38.

Also, the Court does not give any relevance to the fact that Ms Dano and her son benefited from the help of a relative who supported their self-sufficiency; Ms Dano's sister provided food and shelter for both of them.

On this subject, in 2006 the CJEU declared that Belgium failed to fulfil its obligations under the EU Treaties by setting, for citizens of the EU, complete selfsufficiency as a requirement to obtain the right of residency. In the court's understanding, EU Law does not require that the EU citizens provide for their self-sufficiency (including for themselves and their family) individually, instead they can rely on a third party who is willing to provide for them ${ }^{42}$.

Though it is well known that all the EU citizens are granted the right of free movement and residency within the European Union, the ruling of Dano's judgement reminds us of a crucial distinction between citizens according to their economic status - active or inactive.

In regard to the welfare benefits, it seems that only the employed are entitled

\footnotetext{
${ }^{38}$ See ECJ decision on Michel Trojani, op. cit., number 46.

39 The facts that led to the conflict that involved Michel Trojani occurred in light of the EU directive 90/364/CE later replaced by the afore mentioned directive 2004/38/CE.

40 Article 1st paragraph 1 of the directive 90/364/CE

41 See Opinion of Mr. Advocate General Melchior Wathelet, Case C-333/13, delivered on May 20th 2014, numbers 93 and 96, text available at http://eur-lex.europa.eu/legal-content/EN/TXT/ ?qid=1424019087348\&uri=CELEX:62013CC0333.

${ }^{42}$ See ECJ decision on Commission vs. Belgium, dated March 23rd 2006, case C 408/03, number 47, text available at http://eur-lex.europa.eu/legal-content/EN/TXT/?qid=1426119442762\&uri= CELEX:62003CJ0408.
} 
to request a non-contributory cash benefit, whereas for the economically inactive an additional permanent residency title would be required. It should be mentioned that before the adoption of Directive 2004/38, the CJEU had decided that Member States should promote some "financial solidarity" towards nationals from other Member States, namely in those situations regarding the right of residency of temporary nature ${ }^{43}$.

All welfare grant refusals should be met on a case by case basis and never through an automated process which only takes into account the monetary amount to be granted and the impact on the welfare system that it will cause. Each case should also be analysed under the light of the principle of proportionality. ${ }^{44}$ In other words, the simple request from a non-national EU citizen for social security benefits cannot constitute an automatic fundament for its refusal ${ }^{45}$.

On this topic, the German government argued that as a matter of principle, national legislatures are entitled to regulate a great number of cases in an abstract, general way and, on this basis, make classifying decisions. Individual assessments in mass procedures would simply not be feasible in terms of administrative workload $^{46}$.

As some authors point out ${ }^{47}$, the welfare state relies on reciprocity, and courtdriven rights cannot legitimate entitlements that usually require legislative decisions.

This aspect has been highlighted in the Brey Judgement where the CJEU clearly pronounced that no Member State could automatically assume that an EU citizen that resorts to the welfare system is unable to evoke the Directive 2004/38 based solely on the weight that this individual would have on the system.

However, the wording of the Dano judgment undermines such consclusion as a broader interpretation could be used to allow the Member States to deny all social benefits as soon as the economically inactive Union citizen whose residence period is shorter than five years, and who does not have sufficient resources of his/her own. As mentioned by HERWIG VERSCHUEREN"48, "the unreasonability of the burden would not even need to be demonstrated. Yet, such a broad interpretation would be contrary to the objectives of the EU on the free movement for persons, including those who are or who become economically inactive."

\subsection{The Endorsement of National Competences}

Another interesting aspect of the Dano case is the clear endorsement and clarification of the national competences by the CJEU.

\footnotetext{
$\overline{43}$ See ECJ decision on Grzelczylk, op. cit.

${ }^{44}$ See ECJ decision on Brey, dated September 19th 2013, case C $140 \backslash 12$, number 77, text available at http://eur-lex.europa.eu/legal-content/EN/TXT/?qid=1425987252103\&uri=CELEX:62012C I0140.

45 The directive 2004/38 number 16 lists the necessary criteria to determine if a person is an excessive burden to the social security system.

${ }^{46}$ See ECJ decision on Dano, case C-333/13, written observations by the German Government, numbers $81-82$; translated by the author.

47 See Michael Blauberg and Susanne K. Schmidt, "Welfare migration? Free movement of EU citizens and acess to social benfits", Research and Politics, 7 (2014).

48 VERSCHUEREN, Herwig, "Preventing 'benefit tourism' in the EU: A narrow or broad interpretation of the possibilities offered by the ECJ in Dano?", in Common Market Law Review, Vol. 52, Kluwer Law International, 2015, p. 388.
} 
Until recently the Court was accused by the Member States ${ }^{49}$ of extending the EU's competences in matters that would be, at a first sight, part of the Member State's jurisdiction. However, it seems that there is, in the Dano Judgment, a shift of paradigm ${ }^{50}$. The Court took a position on the frontier territory between EU and national competences, and clearly gave prevalence to Member States' jurisdiction denying the applicability of the EU Charter and arguing that the granting of noncontributory cash benefits by way of basic provision was not a matter governed by EU law. According to the Court, as the provisions of the Charter are addressed "to

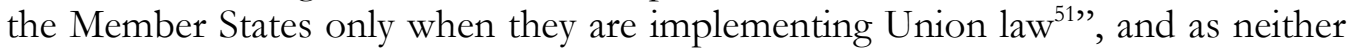
Regulation No 833/2004 nor Directive 2004/38 or any other secondary EU legislation establish the conditions for the attribution of cash benefits to intramigrants EU citizens, only the Member States have competence in this matter. And if the Member States have competence to determine the conditions for granting special non-contributory cash benefits, they also have competence to determine the extent of the social cover provided by that type of benefit.

Member States are free to determine the material conditions and levels of benefit of their social security systems as part of the non-harmonisation principle ${ }^{52}$ applicable in EU social security law. However questions of under what conditions can rights regarding benefit schemes, when they extend to EU citizens and not only to national ones, arise, cannot deem to be solely a national issue. In a certain way, the CJEU abdicates responsibility by handing the fate of Ms Dano back to hands of the national authorities.

\section{Final Notes}

The CJEU's ruling regarding Ms. Dano confirms that the correct balance among the rights of the economically inactive and the Member States' legitimate interests in protecting their welfare systems is still far from being achieved ${ }^{53}$. The message is clear and it states that the heart of the restrictions for economically inactive persons contained in the Directive is not to be altered.

As aforementioned, this ruling undermines the scope of EU citizenship and the meaning of the free movement of persons. It also challenges the backbone principle of the European Union - non-discrimination on grounds of nationality and the right to permanent residency.

From a political point of view, this jurisprudence comes to light at a time

\footnotetext{
${ }^{49}$ In this regard, the United Kingdom has avidly criticised the performance of the CJEU and is presently conducting the project of the investigation "Balance of Competences Review" that consists in the revision of the impact of the actions of the EU in the UK. See https://www.gov.uk/review-of-the-balance-of-competences.

${ }^{50}$ It is important to have a general overview of the jurisprudence of the CJEU. There are several rulings in which the decisions of the Court have led to a general understanding towards the extension of the competences of the EU. To note the previously mentioned ECJ decision on Michel Trojani in which, unlike in Dano, the CJEU decided that the EU citizenship could be, by itself, sufficient as a motive for acquiring the right of residence. Besides Michel Trojani, are worthy of mention, as examples, the rulings Levin, dated March 23 ${ }^{\text {rd }} 1982$, case C-53/81; Vatsouras, dated June $4^{\text {th }} 2009$, joined cases C $-22 / 08$ and $23 / 08$.

51 Article 51, paragraph 1 of the EU Charter.

52 See F. Pennings, "EU citizenship: access to social benefits in other EU member states", International Journal of Comparative Labour Law and Industrial Relations 28 (2012); 307-334.

53 See Steve Peers e Catherine Barnard, Free Movement and Social Benefits for Economically Inactive EU citizens: The Dano Judgment in Historical Context, text available at http://eulawanalysis.blogspot.co.uk L2014/11/free-movement-and-social-benefits-for.html.
} 
when the number of homeless is rising exponentially ${ }^{54}$ and the European Social Rights Committee has issued two decisions regarding complaints against the Netherlands to grant shelter and emergency assistance to foreign nationals without residence status ${ }^{55}$, alleging that this Member State grossly infringed several articles of the European Social Charter.

In conclusion, the current state of affairs in the EU is not the most adequate for the social protection of intra EU migrants. The CJEU acts cautiously and seeks a fair balance in order to avoid a situation in which EU citizenship, while promising a more equal Europe, jeopardizes the solidarity between the Member States through over expansive actions, which could lead to a revival of nationalist sentiments.

However, by trying to find the right balance between the interests of the Member States concerning their financial sustainability and the interests of the EU in seeing its main principles being fully applied, the CJEU seems to compromise the protection of its own citizens, raising doubts concerning legal certainty. If so far, EU citizenship could be enough to guarantee equal treatment and nondiscriminative practices by the Member States, now the panorama seems to be changing.

From a pragmatic point of view, it seems logical that in times like these, a Member State does not have to protect non-national citizens who are not economically active. But on a juridical point of view, this decision seems to undermine important EU principles like the rule of equal treatment and the prohibition of discrimination on grounds of nationality. Most importantly, it leaves us all with uncertainty concerning the protection of EU citizens who move freely between Member States when in a difficult economic situation and it threatens to undermine the acquis of more than 50 years of social security coordination in the EU.

One thing is certain, the CJEU will undoubtedly be confronted with new cases on these issues ${ }^{56}$ and for now, we have to wait to measure the real consequences of the Dano ruling in order to realize if we are or we are not moving forward.

\footnotetext{
54 See Regioplan Policy Research, "Study on Mobility, Migration and Destitution in the European Union”, Brussels, March 2014.

55 See FEANTSA vs. The Netherlands, decision on the merits regarding the complaint $\mathrm{n}^{\circ} 86 / 2013$, dated July $2^{\text {nd }} 2014$ text available at http://www.coe.int/T/DGHL/Monitoring/SocialCharter/ Complaints/CC86Merits en.pdf.

56 See in particular the pending cases: Alimanovic, C-67/14; Talasca, C-19/14; and Commission v. United Kingdom, C-308/14.
} 